$\mathrm{T}$ HE deficit in this year's grain the country's livestock. Shcherbyts'-
harvest can hardly have come at kyy's speech refers, of course, only to a more embarrassing time for the Ukraine, but reports from the other Soviet planners. Just when internal grain areas of the Soviet Union, notpropaganda is aimed at high output ably Kazakhhtan and western Siberia, and increased productivity, at greeting paint a similar picture.

the forthcoming Twenty-fifth Party The emphasis on delivery to the state Congress in a spirit of "socialist emula- of the prescribed quotas is fundamental tion" and celebrating the fortieth to Soviet agricultural policy. In the anniversary of "Stakhanovite" work, early days of collectivisation, this led the Soviet government has had to to considerable wastages. Forbidden by admit, at least at the international Draconian legislation to reap any grain level, that in spite of an ever-expanding for their personal use before the plans programme of the mechanisation and were fulfilled, peasants had to let their electrification of agriculture, the har- horses and oxen starve for lack of feedvest has once again failed to meet the basic requirement of feeding the Soviet population.

Scanning the Soviet press, it is difficult at first glance to find evidence of the deficit. On October 3, when the Soviet government was already seeking abroad the grain which it had failed to produce at home, Radyans'ka Ukrayina reprinted a speech of V. V. Shcherbyts'kyy, First Secretary of the Communist Party of Ukraine, which claimed: "Twenty regions have already fulfilled the agricultural plan [for grain delivery] ... and nine regions have overfulfilled the firm plan." Similar news has peppered the Soviet press throughout August and September. Collective farms, state farms, districts and regions have been reported, one after another, as fulfilling the plan.

Yet when one reads more carefully, a somewhat different picture emerges. Immediately before announcing his apparently promising picture of overfulfilled plans', Scherbyts'kyy had admitted that hopes for a good harvest had fallen victim to "extremely unfavourable weather conditions", but that nevertheless, the total yield would be "considerably higher than in 1972" (cold comfort, since 1972 was the year when crop failures resulted in considerable food shortages). Later in the same speech, he mentioned the importance of guaranteeing adequate supplies of animal feed-implying that this year's reserves were dangerously low, if not actually insufficient. It may well prove necessary to slaughter off a considerable number of cattle on the collective cattle-rearing farms.

It should also be remembered that even if grain production quotas have been fulfilled, in the sense that the requisite amount has been delivered to the official collecting points, a bad harvest may mean that a collective farm is left with no surplus to be shared out for the support of its members and their domestic livestock for the coming year, causing the farm members to become, temporarily, consumers rather than producers, and necessitating a further depletion of

\section{Alien corn?}

from Vera Rich

stuffs, and so had no beasts left to draw the reapers when harvest could officially commence. Although such a situation would hardly be likely today, the precarious balance of Soviet agriculture, officially based on collective or state farms, but in reality deriving a considerable proportion of its vegetables and other small scale products from the personal allotments which the farmers cultivate in their free time is still liable to break down under any unusual conditions. Press announcements that peasants have been stealing "collective" grain to feed to their "private" cow or chickens can hardly account for deficits of millions of tonnes, but do, in some way, symbolise the whole problem of Soviet agriculture. The collective/state farm system simply cannot meet the demands made on it. At the popular level, the solution is that proposed by the TwentyFourth Party Congress: more mechanisation, more extensive use of fertilisers. The theoretical journals, however, show a deeper concern.

Last year, writing in Planovoe khozyaistvo (No. 3, 1974) the Chairman of the State Planning Commission noted a recent falling off of theoretical and methodological work on balancing the economy. Several follow-up articles in the same journal show considerable concern with the balance of the agricultural and industrial sectors. Similarly, writing in Voprosyi ekonomiki (No. 8, 1975), M. Bronshtein, Corresponding Member of the Academy of Sciences of the Estonian SSR made an extensive analysis of the "Economic and Social Problems of the Industrialisation of Agriculture". The word "industrialisation" is significant hereSoviet planners see agriculture as being essentially one more branch of industrial production, amenable to the same system of fulfilment and overfulfilment
of plans. The present trend towards specialisation and concentration of different branches of the "industry" in different areas often, however, takes too little account of the fact that agriculture is what Bronshtein calls a "biomechanical system". His article is tentative and theoretical, but it does reflect a certain awareness that agriculture has its special problems which will not necessarily respond to an industrial-type treatment.

Although such discussions do take place at the theoretical level, however, Party policy demands the acceptance of the fundamental superiority of the Soviet agricultural system. On October 7, the Deputy Minister of Agriculture, A. A. Gol'tsov made a statement in passionate defence of the system. Although the final figures are not yet in, he said, an "average" harvest is expected. The Soviet Union is one of the world's leading grain producers. Grain yields are well up to international standards. Export and import of grain is "normal practice" in international trade. Grain purchases from the USA are intended for the Soviet Far East, to obviate the long haul across the TransSiberian railway. The Soviet Union not only imports grain but also supplies it to other countries. Protesting far too much, he then drew attention to the "steep growth" in agricultural production which has taken place since the 2.3 million tractors and 600,000 combines of today replaced the 17 million wooden harrows of Tsarist times. He stressed the great social benefits that collective farm life has brought to the peasants. Unfortunately, his argument breaks down on one vital fact-Tsarist Russia was a major grain exporter, the "breadbasket of Europe."

Four days later, addressing a rally of collective farmers, the Minister of Agriculture, Dmitrii Polyanskii, spoke far more realistically, admitting that "unusual weather conditions" would inevitably be reflected in the general level of agriculture as a whole. It is one thing, however, to admit a sudden emergency, but another to suggest that the system itself might be at fault. For this reason, although in the present atmosphere of detente the Soviet government is entering into all manner of trade agreements with Western and Third World countries, even in such sensitive areas as oil production or nuclear fuels, there has so far been a considerable reluctance to make some firm agreement on grain purchases. Present negotiations, although described as being in a "very delicate stage", seem, however, to be moving towards the concept of a regular-sales agreement. The stabilisation of the world grain market thus produced would be of long term benefit to both parties. 